\title{
Iheringichthys syi (Siluriformes: Pimelodidae), a new pimelodid species from upper Paraná basin, Brazil
}

\author{
María de las Mercedes Azpelicueta ${ }^{1}$ and Heraldo A. Britski ${ }^{2}$
}

\begin{abstract}
We describe a new species of pimelodid catfish of the genus Iheringichthys from the upper Paraná basin, Brazil. Iheringichthys syi $\mathrm{n}$. sp. is distinguished by the comparatively fine serration along the anterior margin of the pectoral-fin spine, an adpressed dorsal-fin remote from the adipose-fin origin, a large eye (23.2-31.2\% of head length), narrow interorbital (16.2-23.0\% of head length), long snout (42.0-51.0\% of head length), long postorbital length (30.6-34.0\% of head length), low adipose fin (4.8-7.8\% of standard length), eye diameter $97.0-140.0 \%$ of interorbital length, and body with numerous, small dots irregularly scattered on flanks, especially marked on anterior half of flank.
\end{abstract}

Iheringichthys syi sp. n. é descrita para a bacia do alto rio Paraná, Brasil. A nova espécie diferencia-se das duas outras espécies do gênero pelas seguintes características: margem anterior do acúleo da nadadeira peitoral com serra pouco pronunciada, nadadeira dorsal quando adpressa distante da origem da nadadeira adiposa, olho grande $(23,2-31,2 \%$ do comprimento da cabeça), interorbital estreito ( $16,2-23,0 \%$ do comprimento da cabeça), focinho longo ( $42,0-51,0 \%$ do comprimento da cabeça), comprimento pós-orbital relativamente longo (30,6-34,0\% do comprimento da cabeça), nadadeira adiposa baixa (4,8-7,8\% do comprimento padrão), diâmetro do olho 97,0-140,0 \% do espaço interorbital, corpo com numerosas manchas pequenas espalhadas pelo flanco, sendo mais conspícuas na metade anterior do corpo.

Key words: Catfishes, Neotropical region, South-East South America.

\section{Introduction}

The family Pimelodidae comprises many genera with a large number of species, all living in fresh and brackish waters of South America and southern Central America. The family Pimelodidae as defined by Lundberg \& Littman (2003) contains 31 genera and almost 100 species; Ferraris (2007) included 29 genera and 93 species. Among all the genera of the pimelodid assemblage, only two have a combination of a pointed snout, sucking mouth and strongly developed fleshy lips: Iheringichthys and Bergiaria.

Eigenmann \& Norris (1900) founded the genera Iheringichthys for Pimelodus labrosus Lütken, 1874 and Bergiella for Pimelodus westermanni Lütken, 1874. The name Bergiella was preoccupied, and thus Eigenmann \& Norris (1901) proposed the genus Bergiaria, whose members are distinguished from Iheringichthys by the absence of premaxillary teeth. Iheringichthys includes I. labrosus from the río de la Plata in
Argentina and I. megalops Eigenmann \& Ward, 1907 from the upper río Paraguay, in Bahía Negra, Paraguay. Since the last description, the genus has not been revised and no new species were described. In this paper, we describe Iheringichthys syi, a new species from the upper rio Paraná, in Brazil.

\section{Material and Methods}

Measurements are straight-line distances made with a caliper to the nearest $0.1 \mathrm{~mm}$. Measurements follow Lundberg et al. (1991). Proportions are expressed as percentages of standard length (SL), head length (HL). Counts of rays indicate the total number of rays in all fins, the number of specimens between brackets and the holotype marked with an asterisk. Specimens were cleared and stained to obtain osteological characters following Taylor \& van Dyke (1985). Also, dried skeletons were used to compare spines. Institutional acronyms follow Eschmeyer (1998).

${ }^{1}$ Conicet. Museo de La Plata, Paseo del Bosque s/n, 1900 La Plata, Argentina. azpeli@fcnym.unlp.edu.ar

${ }^{2}$ Universidade de São Paulo, Museu de Zoologia, Av. Nazaré 481, 04263-000 São Paulo, SP, Brazil. heraldo@usp.br 


\section{Results}

\section{Iheringichthys syi, new species}

Figs. 1, 2a, 3-5

Holotype. MZUSP 108404, 149.1 mm SL (Fig. 1), Brazil, Mato Grosso do Sul, Três Lagoas Municipality, rio Paraná basin, rio Paraná in Jupiá, 2045'04'’S 5140'42”W, 15 Oct 1962, Excursão Departamento de Zoologia.

Paratypes. Brazil. Mato Grosso do Sul. AI 279, 3 (1 C\&S), 144.0-171.8 mm SL and MZUSP 22507, 15, 109.9-160.5 mm SL, collected with the holotype. MZUSP 22626, 5, 91.2-130.2 mm SL, rio Paraná basin, rio Paraná in front of Jupiá, $20^{\circ} 45^{\prime} 14$ ' $\mathrm{S}$ 51 ${ }^{\circ} 40$ '42”'W, 11 Dec 1960, P.E. Vanzolini, S. Saiar \& J.H. Vanzolini. São Paulo. MZUSP 23082, 3, 133.4-185.0 mm SL, rio Paraná basin, rio Paraná in Ilha Solteira $\left(20^{\circ} 25^{\prime} 45^{\prime}\right.$ 'S 51 20 '00”W), Sep 1965, Excursão Departamento de Zoologia.

Diagnosis. Iheringichthys syi is most readily distinguished from I. labrosus and I. megalops by the presence of only a fine serration on anterior pectoral spine margin, very small serrae on the posterior pectoral-spine margin, and a shorter pectoral fin (16.3-20.1\% SL vs. 20.1-23.2\% in I. labrosus and $20.3-22.3 \%$ in I. megalops). In addition, $I$. syi has a shorter snout (42.0-51.0\% HL vs.56.6-62.0 HL) and a larger eye (23.0$31.2 \%$ HL vs. 22.4-26.7\% HL) than I. labrosus. Furthermore, $I$. syi has a narrow interorbital $(16.2-23.0 \% \mathrm{HL})$, a relatively long postorbital length (30.6-34.0\% HL), low adipose fin (4.8-7.8\% SL), ratio between eye diameter by of interorbital length $97.0-$ $140.0 \%$, adpressed dorsal remote from adipose-fin origin, tip of pectoral fin far from pelvic-fin origin, upper lip curved upward with a very small cleft, and body with numerous, small dots irregularly scattered on flanks, especially marked on anterior half of flank.

Description. Morphometric data for holotype and 26 paratypes presented in Table 1. Medium-sized pimelodid with maximum size of $220 \mathrm{~mm}$ in total length. Dorsal profile of body from snout tip to eye strongly convex, slightly concave across eye and supraoccipital bone, slightly convex from that point to dorsal-fin origin; straight or slightly convex from origin of dorsal fin to origin of adipose fin; slanted ventrally from that point to caudal peduncle, and concave along caudal peduncle. Ventral profile of body straight, slanted dorsally from anal-fin origin to caudal peduncle; caudal peduncle convex.

Maximum body width across cleithra in front of pectoralspine insertion 7.1-9.4 times in SL. Maximum body depth at dorsal-fin origin 4-5 times in SL.

Dorsal fin somewhat triangular, distal margin straight or slightly concave in some specimens. Dorsal-fin origin located at vertical through mid-length of pectoral fin. Tip of adpressed dorsal fin remote from adipose-fin origin, even in small specimens. Dorsal fin lepidotrichia II,6; spinelet short, broad, triangular, with few longitudinal striae, covered by skin. Dorsalfin spine strong, with longitudinal striae; its osseous portion shorter than first branched dorsal-fin ray. Serrae absent on anterior margin, only weak serration present at midlength. Serrae developed posteriorly on distal third of spine very small. Adipose-fin origin located at vertical through posterior fourth of pelvic-fin length. Adipose-fin low (its depth 13.8-17.4 times

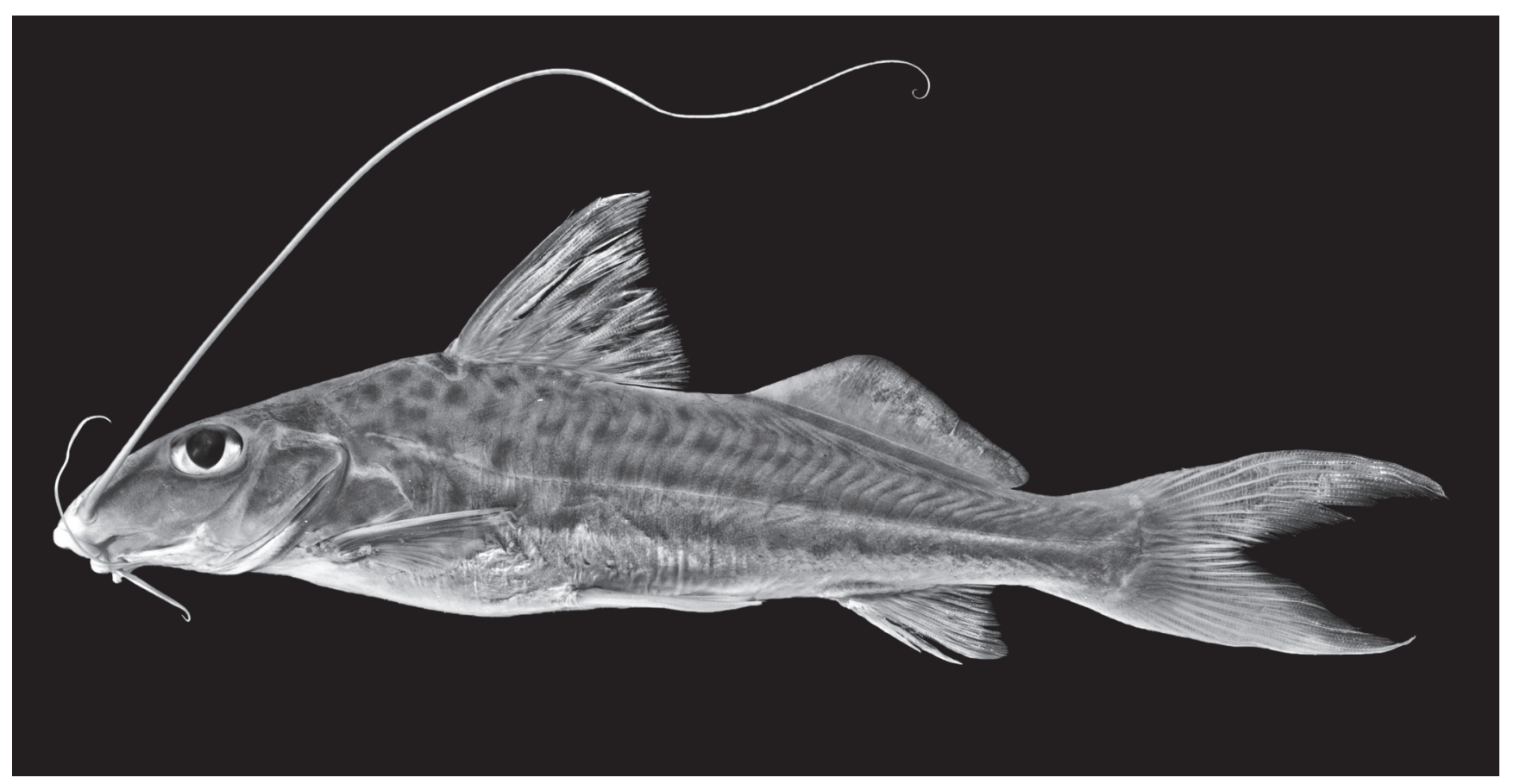

Fig. 1. Iheringichthys syi, MZUSP 108404, holotype, 149.1 mm SL 


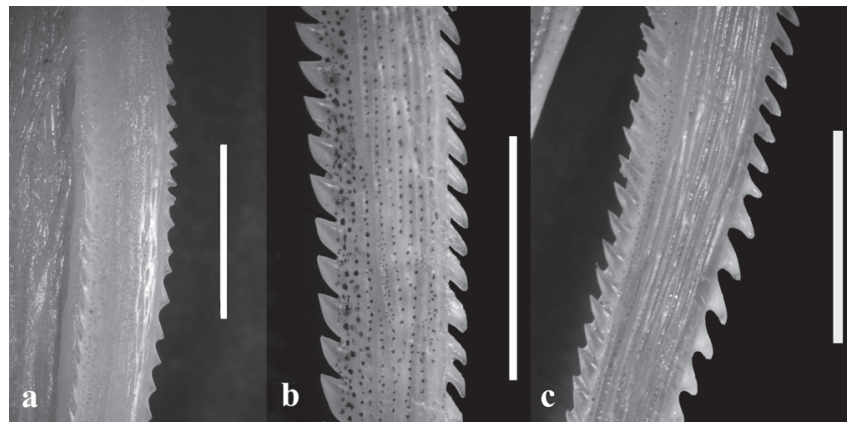

Fig. 2. Detail of the pectoral spine. a, Iheringichthys syi, AI 279, $166.1 \mathrm{~mm}$ SL; b, Iheringichthys megalops, AI 296, 154.0 mm SL; c, Iheringichthys labrosus, AI 280, 200.0 mm SL. Scale bars $=5 \mathrm{~mm}$.

in its length), long (its base 3.3-4.2 times in SL), almost equal in size than head. Caudal fin deeply forked, dorsal lobe elongated, longer than ventral lobe; lower lobe rounded, little wider than upper lobe. Principal caudal-fin rays i,7-8,i. Anal-fin origin located at vertical through first third of adipose fin. Anal fin short, with posterior margin slightly concave; second branched ray longest (one specimen with first branched ray longest), first three branched rays forming small lobe. Anal-fin iv, 7 (2), iv,8 (15), iv, $9(2)$, or v, $8^{*}(7)$ rays.
Pectoral fin with I,9 (2), I,10* (20), or I,11 (4) rays. First branched pectoral-fin ray longer than osseous spine plus its soft portion. Longitudinal striae covering dorsal and ventral surfaces of pectoral spine, less notable on ventral one. Retrorse serrae on posterior margin of spine very fine, small (about 30-32 regularly distributed in spines of $30 \mathrm{~mm}$, less in small specimens), posterior serrae absent in last third of spine in some specimens. Serration along anterior margin of spine fine, always covered by skin, inapparent (Fig. 2a). First branched pectoral-fin ray longer than bony spine plus soft portion. Pectoral axillary gland pore, above posterior portion of pectoral fin, very close to ventral margin of cleithral process. Cleithral surface covered by very fine tubercles; posterior cleithral process broad, scarcely pointed forming almost straight angle. Pelvic-fin origin located at vertical through last dorsal-fin ray, fin tip reaching posterior third of distance between pelvic and anal fin origins. Pelvic fin with i,5 rays. Inner fin rays covering anus and urogenital papillae.

Head triangular in dorsal view, of moderate length (contained 3.1-3.5 times in SL), relatively deep (its depth at base of supraoccipital process equal to body width or scarcely less). Head covered by thin skin; roof of skull, especially posterior part and supraoccipital posterior process ornamented with tubercles and striae. Numerous branches of laterosensory canal system expanded between eye and

Table 1. Morphometric data of holotype and 26 paratypes of Iheringichthys syi. Min $=\operatorname{minimum} ; \mathrm{Max}=\operatorname{maximum} ; \mathrm{SD}=$ Standard Deviation; SOC = Supraoccipital Process.

\begin{tabular}{|c|c|c|c|c|c|}
\hline & Holotype & Min. & Max. & Mean & SD \\
\hline $\mathrm{SL}(\mathrm{mm})$ & 149.10 & 91.22 & 185.00 & - & - \\
\hline \multicolumn{6}{|c|}{ Percents of Standard Length } \\
\hline Predorsal length & 40.37 & 38.19 & 42.11 & 39.91 & 0.0096 \\
\hline Preventral length & 50.10 & 46.44 & 51.95 & 49.29 & 0.0120 \\
\hline Preanal length & 76.76 & 70.82 & 77.12 & 74.69 & 0.0160 \\
\hline Origin of pectoral fin/origin of pelvic fin & 24.93 & 21.92 & 25.48 & 23.99 & 0.0096 \\
\hline Origin of pelvic fin/origin of anal fin & 27.22 & 24.32 & 28.54 & 26.15 & 0.0100 \\
\hline Dorsal-spine length & 22.45 & 17.35 & 23.84 & 21.07 & 0.0140 \\
\hline Dorsal-fin base & 14.80 & 14.16 & 18.12 & 15.19 & 0.0083 \\
\hline Adipose-fin base & 25.51 & 23.46 & 27.03 & 25.11 & 0.0100 \\
\hline Adipose-fin height & 5.58 & 4.89 & 7.81 & 6.30 & 0.0059 \\
\hline Pectoral-spine length & 16.86 & 16.39 & 20.13 & 18.35 & 0.0111 \\
\hline Ventral-fin length & 17.46 & 17.46 & 20.36 & 18.59 & 0.0079 \\
\hline Anal-fin base & 10.45 & 8.42 & 11.60 & 9.68 & 0.0076 \\
\hline Body depth & 20.83 & 18.86 & 24.43 & 21.23 & 0.0146 \\
\hline Caudal peduncle depth & 8.30 & 7.66 & 9.00 & 8.20 & 0.0030 \\
\hline Caudal peduncle length & 19.50 & 14.81 & 19.52 & 17.36 & 0.0101 \\
\hline Head length & 30.63 & 27.90 & 31.93 & 29.93 & 0.0102 \\
\hline Posterior SOC length & 8.50 & 6.48 & 8.87 & 7.86 & 0.0057 \\
\hline Posterior SOC width & 5.42 & 4.06 & 6.65 & 5.61 & 0.0053 \\
\hline \multicolumn{6}{|c|}{ Percents of Head Length } \\
\hline Head depth & 56.85 & 52.41 & 64.61 & 59.04 & 0.0340 \\
\hline Head width & 61.56 & 53.29 & 65.01 & 59.20 & 0.0258 \\
\hline Head width at nares & 28.40 & 28.40 & 38.50 & 32.51 & 0.0198 \\
\hline Snout length & 46.35 & 42.06 & 52.65 & 46.83 & 0.0254 \\
\hline Horizontal orbital diameter & 25.81 & 23.30 & 32.24 & 27.23 & 0.0239 \\
\hline Interorbital length & 20.85 & 16.22 & 24.88 & 21.37 & 0.0192 \\
\hline Postorbital length & 31.09 & 30.61 & 35.37 & 32.09 & 0.0114 \\
\hline Snout to anterior nare & 14.80 & 10.54 & 16.14 & 13.61 & 0.0148 \\
\hline Distance between nares & 10.77 & 9.62 & 13.76 & 12.09 & 0.0104 \\
\hline Posterior nare/anterior margin of eye & 22.56 & 16.44 & 23.98 & 19.52 & 0.0191 \\
\hline
\end{tabular}




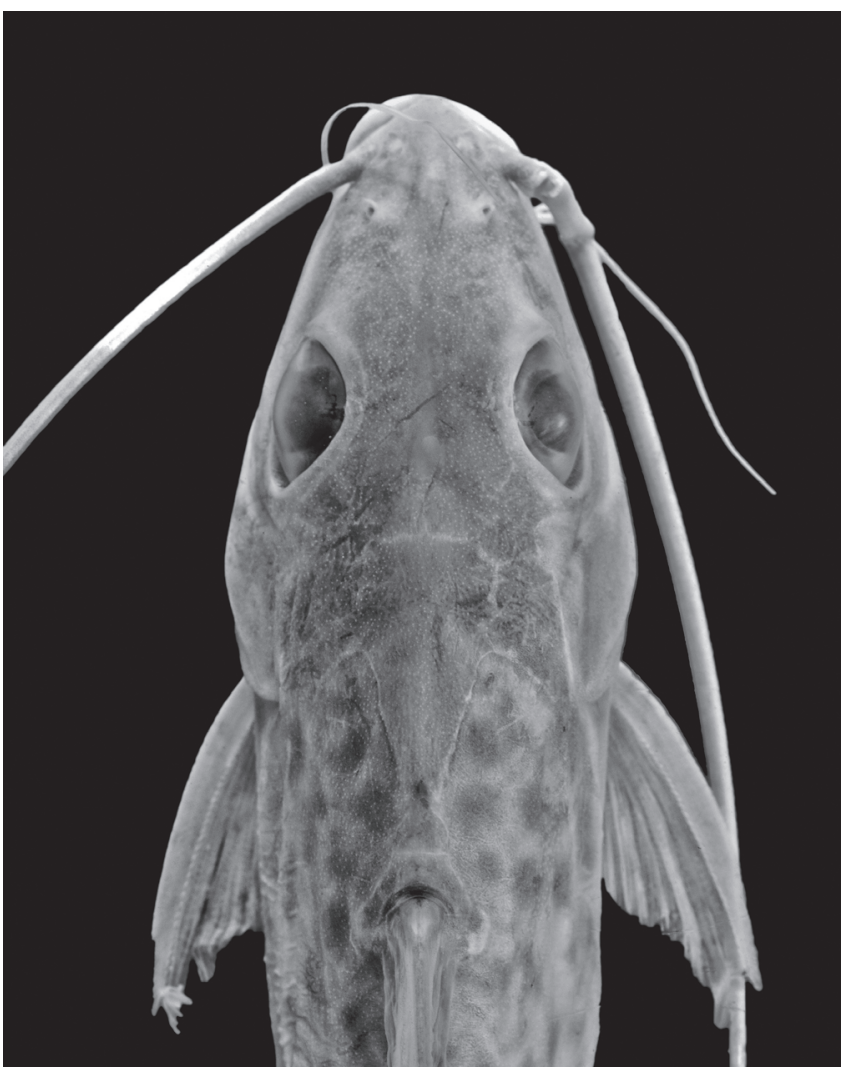

Fig. 3. Iheringichthys syi, MZUSP 108404, holotype, 149.1 $\mathrm{mm}$ SL, dorsal view of head and pectoral fins.

posterior tip of supraoccipital process. Anterior orbital ridge very low, formed by frontal bone. Snout long, pointed (contained 1.9-2.2 times in HL). Anterior cranial fontanelle narrow, oval, anterior margin nearer to posterior nostril than eye and finished before posterior margin of eye. Posterior fontanelle absent. Supraoccipital posterior process prominent, pointed (contained 1.9-2.2 times in HL), longer than wide reaching nuchal plate (Fig. 3); its dorsal surface strongly angular in cross section, sharply rounded. Anterior nostril with short tubular rim, located at level of maxillary barbel insertion; posterior nostril preceded by large anterior membrane covering almost completely oblique opening. Distance between snout and anterior nostril longer than distance between nostrils (Fig. 3).

Eye large, placed laterodorsally, located little behind midpoint of head. Interorbital space flat, scarcely concave behind this area; interobital narrow (0.7-0.9) times eye diameter.

Mouth very small, ventral (Fig. 4). Upper jaw projecting. Fleshy lips prominent (width of lower lip about 0.5 times in width of upper lip); upper lip curved upward with small median cleft. Premaxillary teeth completely or partially exposed with mouth closed. Premaxillary tooth band slender, its transverse axis short; its posterolateral corner bluntly rounded; its anterior margin slightly rounded. Premaxillary teeth conical, fine. Dentary tooth band wider at symphysis, with teeth of similar shape.

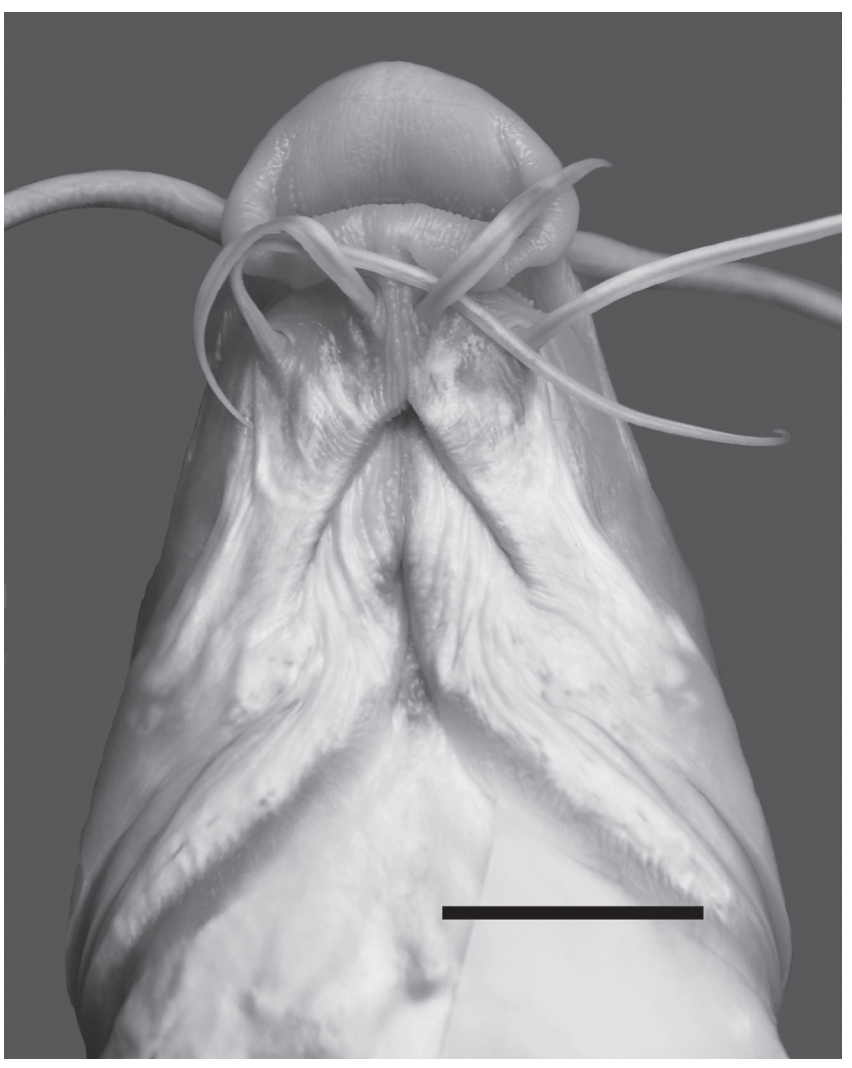

Fig. 4. Iheringichthys syi, AI 279, paratype, $166.1 \mathrm{~mm} \mathrm{SL}$, detail of the mouth. Scale bar $=8 \mathrm{~mm}$.

Maxillary barbel originated at low sulcus between anterior nostril and eye; maxillary barbel long, usually reaching procurrent caudal-fin rays; sometimes longer, ending about midlength of caudal lobes. Lateral mental barbel surpassing pectoral-fin origin. Tip of medial mental barbel scarcely reaching branchiostegal membrane. Branchiostegal membranes diverging without overlap.

Inner surface of bucal cavity with rounded or filamentous papillae, larger and more abundant in large specimens. Skin of anterior and posterior surfaces of all branchial arches covered with papillae. Size of papillae smaller on anterior face of first and reduced fifth arches, and posterior face of fourth arch. Papillae developed on anterior surface of first arch and posterior surface of fourth arch rounded or conical, close to branchial filaments. Anterior surfaces of second to fifth arches, and posterior surfaces of first to third arches covered by broad papillae located transverse to longitudinal axis of arch (Fig. 5a). Larger, broad papillae with crenate margins. Skin around pharyngeal tooth plates covered by numerous papillae.

Gill rakers lobate (Fig. 5b), distributed as follows on first gill arch: 4 (1), $5^{*}(20)$, or 6 (6) on upper limb; 1 on cartilage, and $14(1), 15(6), 16^{*}(10), 17(4)$, or 18 (2) on lower limb ( $\mathrm{n}=$ 23). Gill rakers absent on second to fifth arches.

Lateral line complete; side-branch tubules of laterosensory canals alternatively directed horizontally and posteroventrally, 


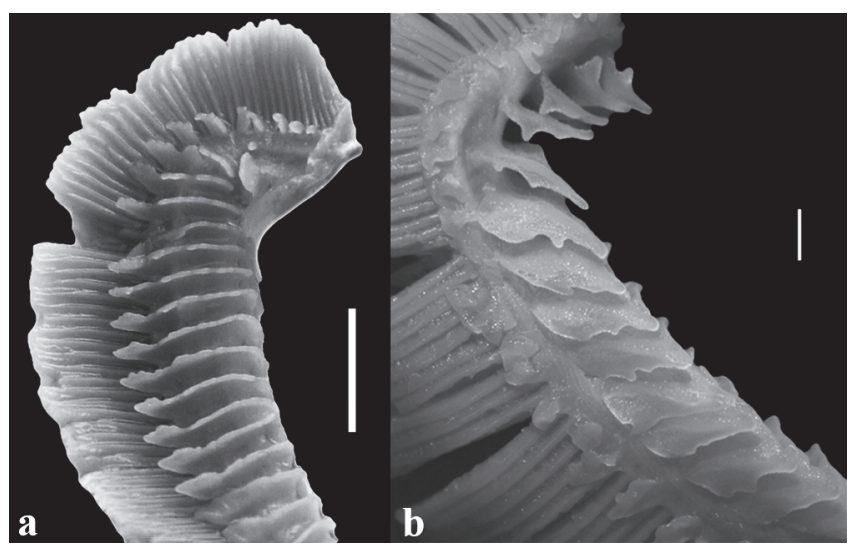

Fig. 5. Iheringichthys syi, AI 279, paratype, $171.8 \mathrm{~mm} \mathrm{SL.} \mathrm{a)}$ detail of the papillae on skin of posterior surface of the first branchial arch. Scale bar $=5 \mathrm{~mm} ; \mathbf{b})$ detail of the gill rakers on first branchial arch. Scale bar $=1 \mathrm{~mm}$.

from head to vertical between pelvic-fin origin and short distance after last dorsal-fin ray insertion.

Urogenital papilla with numerous small ephitelial folds, forming furrows, placed between anus and urogenital papillae. Also small folds developed laterally to anus in large specimens.

Margins of swimbladder straight; swimbladder heartshaped, with three incomplete, large chambers. Sonic muscles inserted ventrolaterally on anterior third.

Color in alcohol. Background brownish, scarcely darker on dorsum; lower third of flanks cream, without dots. Many brown spots irregularly distributed on flanks. Spots more numerous on anterior half or two-thirds of body; spots very faint or absent on posterior half or third of body. Spots of anterior part of body, close to head, smaller. Very narrow horizontal line pale whitish, crossing flanks at level of pores of lateral line sensory canals in most specimens. Dorsal surface of head and cheeks light brown, without dots. Black chomatophores at dorsal-fin origin and around nuchal plates.

Distribution. The species is found in Brazil from the upper rio Paraná, in Jupiá (Três Lagoas Municipality, Mato Grosso do Sul State) and Ilha Solteira Municipality (São Paulo State). All specimens of Iheringichthys examined from those areas belong to I. syi. Most -and possibly all- records of Iheringichthys labrosus from those areas likely correspond to $I$. syi.

Etymology. The Guaraní word syi means straight, here alluding to the fine serration present on anterior margin of the pectoralfin spine. The name is applied as an adjective.

\section{Artificial key for Iheringichthys species:}

1a. Anterior margin of pectoral-fin spine with fine serration, inapparent Iheringichthys syi

1b. Anterior margin of pectoral-fin spine with well developed serrae 2a. Horizontal orbital diameter 27.3-32.0\% of HL; snout length 44.3-46.7 \% of HL; adipose-fin length $92.5-100.7 \%$ of distance between dorsal-fin origin and adipose-fin origin .. Iheringichthys megalops 2b. Horizontal orbital diameter $22.4-26.7 \%$ of HL; snout length 47.0-51.7 \% of HL; adipose-fin length 79.7-88.9 \% of distance between dorsal-fin origin and adipose-fin origin . Iheringichthys labrosus

\section{Discussion}

The three species of Iheringichthys share the presence of pointed snout, with small and ventrally directed mouth bordered by prominent fleshy lips, and the upper lip curved upward, a development of numerous epithelial papillae on the skin of inner surface of bucal cavity, opercular bones, branchial arches, and within the area around pharyngobranchial tooth plates, and the absence of gill rakers in the branchial arches two to five. Iheringichthys syi is easily distinguished from its congeners by the presence of only fine serrations on the anterior pectoral-spine margin; I. labrosus and Imegalops have distinct serrae on the anterior and especially the posterior pectoral spine margins (Fig. 2). Iheringichthys syi has shorter dorsal-fin rays; the tip of the fin, when adpressed, falls far from the adipose-fin origin whereas in both I. megalops and $I$. labrosus the tip of adpressed dorsal fin comes close to the adipose-fin origin or even reaches it in I. labrosus (Figs. 6 and 7). Iheringichthys syi has a relatively shorter postorbital length (30.6-34.0\% HL vs. 33.0-36.4\% HL in I. labrosus and 33.1-36.2 in I. megalops). Iheringichthys syi has many dots irregularly distributed on anterior two thirds of flanks, being faint or lost on posterior half of body; the spots scattered on body of $I$. labrosus are more numerous and irregularly placed along the flanks, although some specimens either have no dots or the dots are very faint in the posterior portion of the body. Iheringichthys megalops have small spots distributed all over the flank or with spots faint in the posterior portion of body (Figs.6 and 7).

In the original description of I. megalops, based on only a single specimen, the authors commented that the supraoccipital posterior process was of greater width than length. Nonetheless, an examination of the holotype shows a typical triangular process longer than wide (width at base $10.8 \mathrm{~mm}$, length $13.5 \mathrm{~mm}$ in the holotype, i.e., with the width at $80 \%$ of the length). Moreover, the tip of the pectoral fin is close to the pelvic-fin origin and the tip of pelvic fin reaches the anal-fin origin. In Iheringichthys syi, the tips of the pectoral and pelvic fins are remote from the origins of pelvic and anal fins respectively.

The fine serration developed on the anterior margin of the pectoral spine of Iheringichthys syi resembles that of Bergiaria westermanni, in which minuscule serrae occur on the anterior margin of pectoral spine. Bergiaria westermanni and B. platana (Steindachner, 1908) possess some of those characters mentioned for Iheringichthys such as the shape of the mouth, the development of large, fleshy lips, and the 

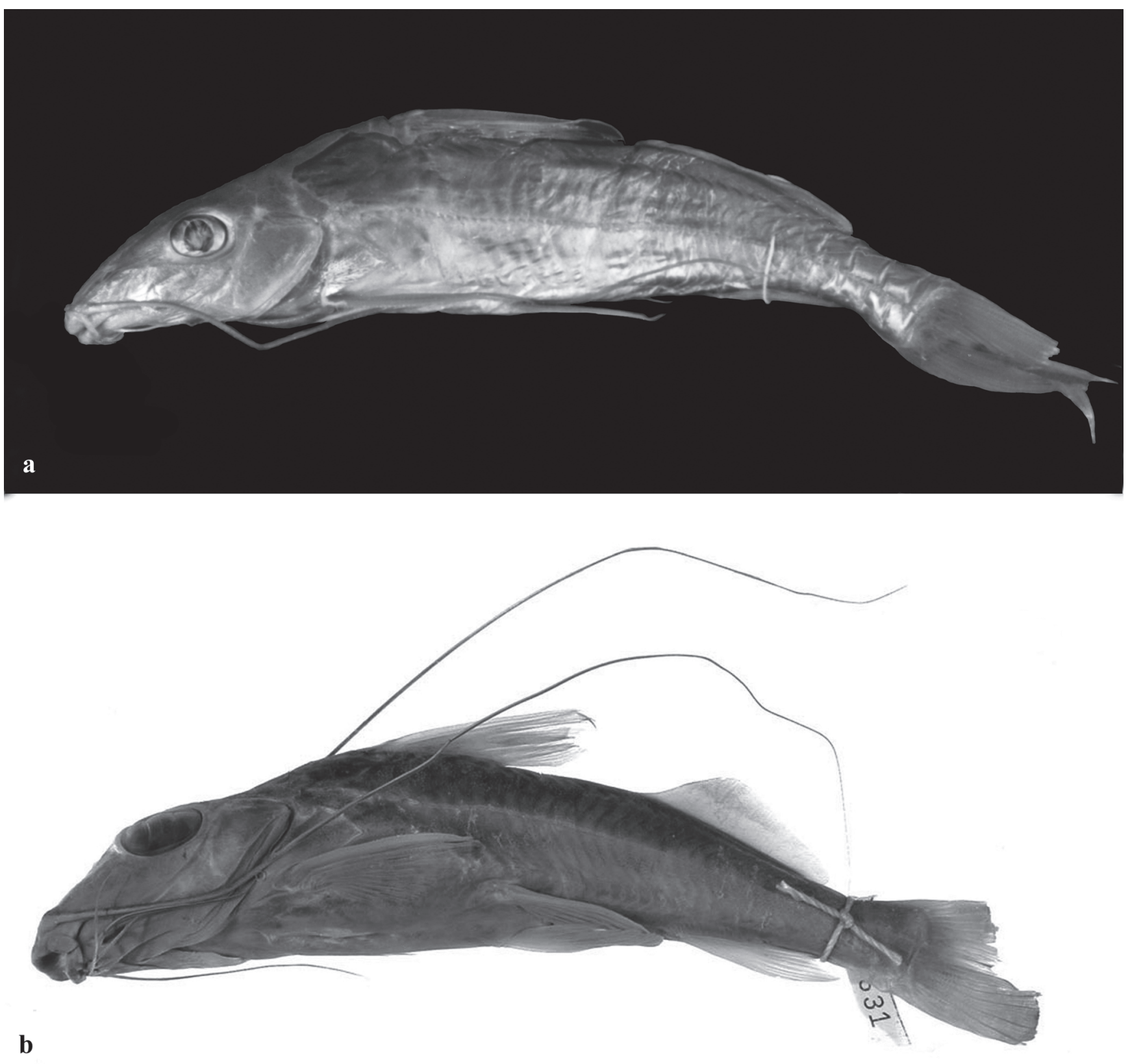

Fig. 6. a) Iheringichthys labrosus, ZMUC 258, syntype, $124.0 \mathrm{~mm}$ SL; b) Iheringichthys megalops, CAS 63631, holotype, 143.0 $\mathrm{mm}$ SL, photograph obtained from the Primary Type Imagebase of California Academy of Sciences.

presence of papillae on the skin of cheeks and branchial arches, but differs from species of Iheringichthys by the lost of premaxillary teeth. A phylogenetic study is in progress to clarify the taxonomic validity of Bergiaria.

Elongated papillae transversely arranged on skin of the branchial arches, of similar size and shape, occur in Cheirocerus Eigenmann, 1917 (Stewart \& Pavlik, 1985). Those structures probably evolved independently in both genera because the species of Cheirocerus have a number of unusual characters including complex mouth with an upper lip forming a deep pocket, a crimped edge in the swimbladder which has two slender hollow tubes extending anterolaterally, and the spine locking mechanism lost because the spinelet is rudimentary and the second unbranched ray remains flexible, all of which suggest that the two genera are not closely related.

Material examined. Bergiaria westermanni. Brazil. rio São Francisco basin. Bahia. ANSP 172139, 2, riacho Santana (isolated stagnant pools) $3.1 \mathrm{~km} \mathrm{~S}$ of Bom Jesus da Lapa on road to Malhada. Minas Gerais. ANSP 172140, 1, rio das Velhas, approximately 35 km NE of Curvelo. MZUSP 2218, 3, córrego do Cedro. MZUSP 


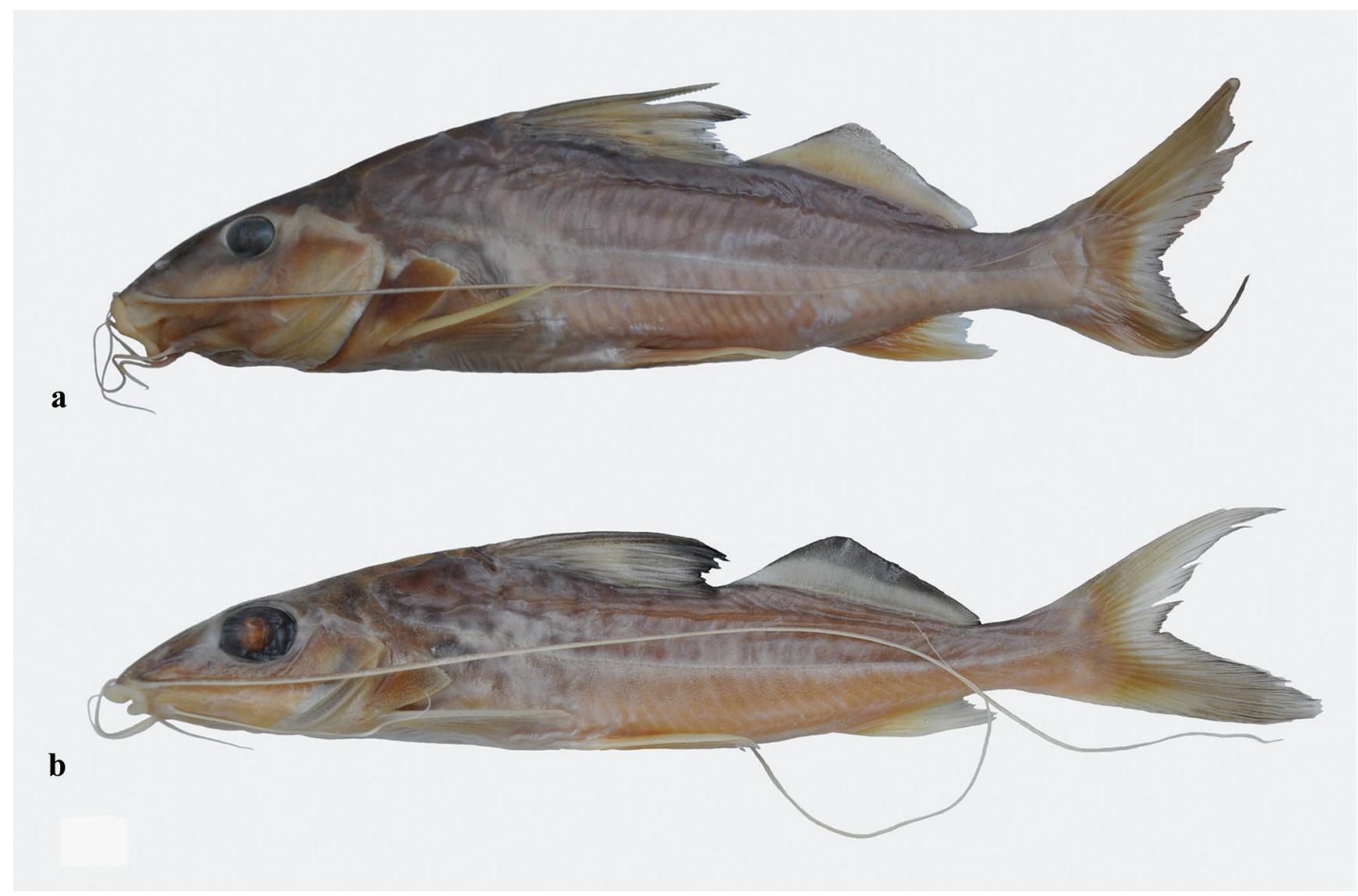

Fig. 7. a) Iheringichthys labrosus, AI 280, $200.00 \mathrm{~mm}$ SL; b) Iheringichthys megalops, AI 296, $154 \mathrm{~mm}$ SL.

24641, 2, rio São Francisco in Três Marias. MZUSP 39321, 1, córrego do Cedro. USNM 044977, 2, rio das Velhas. ZMUC 258, syntype, rio das Velhas without precise locality. Bergiaria platana. Argentina. Buenos Aires. AI 281, 5, río de la Plata basin, río de la Plata in La Plata City. Cheirocerus goeldii. Brazil. AI 278, 1, rio Solimões without precise locality. Iheringichthys labrosus. Argentina. Corrientes. AI 280, 5 (3 C\&S, 1 dried), río Uruguay basin, río Uruguay in Monte Caseros. Buenos Aires. ZMUC 255, syntype, río de la Plata basin, río de la Plata without precise locality. Iheringichthys megalops. Argentina. Misiones. AI 296, 2 (1 dried), río Paraná basin, río Paraná in Oro Verde. Brazil. Mato Grosso do Sul. MZUSP 25102, 1, rio Paraguay basin, rio Paraguay in Corumbá. Paraguay. Alto Paraguay. CAS 63631, holotype, río Paraguay basin, río Paraguay in Bahía Negra. Distrito Capital. USNM 181447, 3, río Paraguay basin, río Paraguay in Asunción. USNM 181435, 1, río Paraguay basin, río Paraguay in Asunción. Paraguari. ANSP 176169, 3, río Paraguay basin, río Tebicuary, mud beach on Parador Las Mercedes side of inlet. Pimelodus fur. Brazil. Minas Gerais. ZMUC 286, syntype, 120.0 mm, rio São Francisco basin, rio das Velhas without precise locality. Pimelodus paranensis. Brazil. São Paulo. MZUSP 23089, holotype, 230.5 mm, río Paraná basin, rio Paraná at Ilha Solteira.

\section{Acknowledgments}

We thank the staff of Proyecto Pesquero Regional (UNAM) for donation of material, Carl Ferraris Jr. (CAS) for hand-carrying the holotype of I. megalops from California to La Plata, David Catania (CAS) for permission to use the CAS primary type imagebase, Jorgen Nielsen (ZMUC) for loan of type material and provision of old literature, John Lundberg and Mark Sabaj Pérez for their friendly help in The Academy of Natural Sciences of Philadelphia, Richard Vari (USNM) for permission to examine material under his care, Stefan Körber for translation of German literature, Soledad Gouiric Cavalli and Daniel Cabrera (MLP) for help with photographs under stereomicroscope, Leandro M. Souza (MZUSP) for photographs of the holotype, three anonymous reviewers improved the manuscript, the Agencia Nacional de Promoción Científica y Tecnológica (PICT 913), the All Catfish Species Inventory Project, and the Consejo Nacional de Investigaciones Científicas y Técnicas (PIP 5365) for financial support.

\section{Literature Cited}

Eigenmann, C. H. \& A. A. Norris. 1900. Sobre alguns peixes de São Paulo, Brazil. Revista do Museu Paulista, 4: 349-362.

Eigenmann, C. H. \& A. A. Norris. 1901. Comunicaciones del Museo Nacional de Buenos Aires, 1: 272.

Eschmeyer, W. 1998. Catalog of fishes. Volume 1. California Academy of Natural Sciences, KNI Incorporated, Anaheim, California, 958p. 
Ferraris, C. J., Jr. 2007. Checklist of catfishes, recent and fossil (Osteichthyes: Siluriformes), and catalogue of siluriform primary types. Zootaxa, 1418: 1-628.

Lundberg. J. G. \& M. W. Littmann. 2003. Family Pimelodidae (Longwhiskered catfishes). Pp. 432-446. In: Reis, R. E., S. O. Kullander \& C. J. Ferraris Jr. (Eds.). Check list of the Freshwater Fishes of South and Central America. Porto Alegre, Edipucrs, 729p.

Lundberg, J. G., F. Mago-Leccia \& P. Nass. 1991. Exallodontus aguanai, a new genus and species of Pimelodidae (Pisces, Siluriformes), from deep river channels of South America and delimitation of the subfamily Pimelodinae. Proccedings of the Biological Society of Washington, 104(4): 840-869.

Stewart, D. J. \& M. J. Pavlik. 1985. Revision of Cheirocerus (Pisces: Pimelodidae) from tropical freshwaters of South America. Copeia, 1985(2): 356-367.

Taylor, W. R. \& G. C. van Dyke. 1985. Revised procedures for staining and clearing small fishes and other vertebrates for bone and cartilage study. Cybium, 9: 107-119.

Submitted March 16, 2011

Accepted October 26, 2011

Published March 30, 2012 